\title{
Effects of Low-Methoxyl Pectin on Physicochemical and Sensory Proper- ties of Reduced- Calorie Sorrel/ Roselle (Hibiscus sabdariffa L.) Jams
}

\author{
Jacklyn Broomes and Neela Badrie*
}

Department of Food Production, Faculty of Science and Agriculture, University of the West Indies, St. Augustine, Republic of Trinidad and Tobago, West Indies

\begin{abstract}
Low-fat/ reduced calorie products were originally targeted for diabetics but now the focus is on healthiness. The global prevalence of diabetes is on the increase and may be addressed by controlling the total dietary carbohydrate and calorie intake. This study investigated the effects of low-methoxyl (LM) pectin on physiochemical and sensory properties of a reduced-calorie sorrel (Hibiscus sabdariffa) jam with sucralose. Sorrel calyces were treated with $0.5 \%$ pectolase to form puree. The puree was processed to jam at $90^{\circ} \mathrm{C}$ for 30 minutes, then at $100^{\circ} \mathrm{C}$ for 2 minutes upon the addition of $8 \%$ sucralose and three levels $(1.5,2.0,2.5 \%)$ of calcium added LM pectin for gelation. The addition of xanthan gum was at $2 \% \mathrm{w} / \mathrm{w}$. The effects of higher LM pectin increased $(\mathrm{P}<0.01)$ the moisture content and texture but reduced water activity and total titratable acidity. The additional varying levels of LM pectin resulted $(\mathrm{P}<0.05)$ in lighter, more chromatic and less bluish-red colored jam. The texture became firmer $(\mathrm{P}<0.01)$ with higher levels of LM pectin. A sorrel jam with $1.5 \% \mathrm{LM}$ pectin had total soluble solids of $16^{\circ} \mathrm{Brix}, 0.96 \%$ citric acid and $\mathrm{pH} 3.3$. This treatment was liked slightly to moderately in texture and overall acceptance. On storage the jam became less $(\mathrm{P}<0.01)$ bright and bluish-red on storage at $4^{\circ} \mathrm{C}$ for 28 days. Most panelists would purchase the reduced - calorie sorrel jam.
\end{abstract}

Keywords: Sorrel, Hibiscus sabdariffa, sorrel/roselle, reduced-calorie, low-methoxyl pectin, sucralose, texture.

\section{INTRODUCTION}

The development of reduced/low-calorie foods was originally targeted to specific consumers with health issues such as diabetes and obesity. However, their use has been expanded to disease prevention, to weight control and to fit within the pattern of a healthier diet and lifestyle [1]. On the shelves of groceries and supermarkets many traditional jams with $65 \%$ soluble solids [2] are readily available for consumption. Regular utilization of these jams along with other high calorie foods can lead to an increased glucose concentration in the blood leading to hyperglycemia $(180 \mathrm{mg} / \mathrm{dl}$ and above) [3]. Unconventional jams should be developed utilizing low-calorie, high intensity sugar substitutes such as sucralose (1, 6-dichloro-1, 6-dideoxy- $\beta$-D-fructofuranosyl-4chloro-deoxy- $\alpha$-D-galactopyranoside) which is quoted as a non-caloric sweetener and sucrose derivative approximately 600 times as sweet as sucrose. Therefore, very small amounts of sucralose are adequate to achieve the desired sweetness in low-calorie jams [4]. High-intensity sweeteners provide only sweetness, combining bulking agents such lowmethoxyl (LM) pectin can provide the functional properties of sugar in food without the calories. Studies have shown that LM pectins $(<50 \%$ esterified), often used in low-sugar products, form gel-forming properties with or without only a small amount of sugars in the presence of $\mathrm{Ca}^{2+}$ and at low $\mathrm{pH}(<3.5)[5,6]$. This results in products with a low content/percentage of total soluble solids [7]. In addition, pectin is well recognized as a dietary fiber playing a significant role

*Address correspondence to this author at the Department of Food Production, Faculty of Science and Agriculture, University of the West Indies, St. Augustine, Republic of Trinidad and Tobago, West Indies; Tel: 1-868-6622002 ext 3211 or 2090; Fax: 1-868-645-0479;

E-mail: nbadrie@yahoo.com; neela.badrie@sta.uwi.edu in reducing the risks of high-life style related diseases such as obesity and diabetes [8].

The worldwide prevalence of type 2 diabetes is alarmingly high and is predicted to increase from $2.8 \%$ in 2000 to $4.4 \%$ in 2030 [9]. In the developing countries, the prevalence of diabetes is predicted to change from $2.4 \%$ to $4.0 \%$ within the same 30 year period. The increase in diabetes is directly related to the increased incidence of obesity [10]. At least $80 \%$ of the Caribbean population burden of diabetes could be attributed to the presence of overweight/obesity in the population (BMI>25) [11]. In the Caribbean, $25 \%$ of women are obese (BMI $>30$ ) which is almost twice as many of the male counterparts [12]. Two major contributions to the over supply of calories are fats and sugars. The Caribbean region has more than $160 \%$ of the average requirement for fats and excess of $250 \%$ for sugars [13]. Overall, $17.5 \%$ of Barbadians have diabetes and $2 \%$ of the study population had a measure of diabetes without any prior history of diabetes [14].

Sorrel (Hibiscus sabdariffa) is a plant from the Malvaceae family. It is known as sorrel, jamaica or roselle in the Caribbean [15]. The red pigments of sorrel calyces contain anthocyanins [16] that are soluble flavonoid pigments in water, natural phenolics [17] and potential natural antioxidant $[18,19]$. The two main anthocyanins identified in sorrel were delphinidin and cyanidin [20]. Anthocyanins in fruits and fruit products are susceptible to color loss [21]. Heat, $\mathrm{pH}$, oxygen and various storage conditions are known to have marked effects on anthocyanin stability [22, 23]. Sorrel has medicinal and health benefits [24]. The interest in anthocyanin pigments has accelerated in recent years because of their possible role in reducing the risk of coronary heart disease, cancer, stroke [25] certain epithelial cancers, visual 
impairments, arthritis and asthma [26-33]. Anthocyanin pigments have been recognized in disease prevention through their effects on oxidative damage [34-36].

A number of novel products has been developed from sorrel calyces such as wines [37, 38] sorrel sauces [39], stirred-sorrel yoghurts, [40] sorrel cheese [41], and drinks $[42,43]$. The sorrel calyces are rich in ascorbic acid and pectin and are ideal in producing a brilliant red coloring for making jams, jellies, etc. [24, 44]. The literature is limited on the use of high intensity sweeteners in conjunction with lowmethoxyl pectin in the production of low and reduced-calorie jams for the diabetic market. The use of sorrel in jams has not been mentioned anywhere. Therefore, the hypothesis of this research is that varying levels of low-methoxyl pectin in combination with a standard level of high intensity sweetener will produce a reduced-calorie sorrel jam of desired gelling characteristics which carries sensory attributes that are acceptable to consumers and are of adequate shelf stability. Therefore, the objectives were to (1) develop a reducedcalorie sorrel jam using sucralose in the form of Splenda and (2) investigate the effects of adding low-methoxyl pectin on the physiochemical and sensory properties of reduced-calorie sorrel jam.

\section{MATERIALS AND METHODS}

\section{Processing of Reduced -Calorie Sorrel Jam}

Sorrel calyces (Hibiscus sabdariffa) were sourced from a local market and processed at $90^{\circ} \mathrm{C}$ for 30 minutes in water (50: 50) with $0.13 \% \mathrm{w} / \mathrm{w}$ ground allspice (Pimenta dioica; McCormick, Hunt Valley, Mcl). Pectolase enzyme (0.5\% w/w of sorrel calyces; Young's Home Brew and Allied Products Limited, Bilston West Midlands, MV 148D2) was added to cooled $\left(30^{\circ} \mathrm{C}\right)$ water-processed calyces for 24 hours. The enzyme-treated sorrel puree was sieved through 2 $\mathrm{mm}$ sieve (U.S.A Standard Testing Sieve A.S.T.M. E-11) and stored at $4^{\circ} \mathrm{C}$ for further analyses.

The formulations of three reduced-calorie sorrel jam treatments are given in Table $\mathbf{1}$. They were decided based on focus group evaluation using 15 untrained persons who were asked to give an early evaluation of the jam prototypes according to flavor, sweetness, acidity, color, texture, odor and overall acceptability. All panelists were regular consumers of jams and were willing participants. Their opinions were then taken into account for the preparation of the final jam treat- ments. These treatments comprised of $8 \% \mathrm{w} / \mathrm{w}$ standardized Splenda (sucralose, Splenda, McNeil PPC, Inc., New Brunswick, N.J. and $1.5 \%, 2.0 \%$ and $2.5 \%$ w/w pectin with calcium water (Pomona Universal Pectin, Workstead Industries, Greenfield MA, USA) which were evaluated for sensory evaluation. Low methoxyl (LM) pectins (with DE $<50 \%$ ) form rigid gels by the action of calcium or multivalent cations, which cross-link the galacturonic acid chains [45].

The weight of the sorrel in each jam was 55\% of the total mixture according to CODEX STAN 79-81 [2] for jam , $0.1 \%$ xanthan gum (Colloids Naturals Inc, Hammond, IN), $0.05 \%$ sodium benzoate DSM, Heerlan, Netherlands) and the pectin and calcium water ratio (1:1) for each treatment.

Fig. (1) shows the processing steps for the reduced calorie sorrel jam. The sorrel puree, water and calcium water were heated at $90^{\circ} \mathrm{C}$ for 30 minutes. The low-methoxyl pectin, sucralose and xanthan gum were vigorously stirred and heated at $90^{\circ} \mathrm{C}$, the mixture and cooled $30^{\circ} \mathrm{C}$. The $\mathrm{pH}$ of the mixture was then tested and recorded. If the $\mathrm{pH}$ recorded was less than 3.3, it was adjusted with food-grade sodium hydroxide to the required $\mathrm{pH} 3.3$. The sodium benzoate was then incorporated. The mixture was processed at $95^{\circ} \mathrm{C}$ for 1 2 minutes and hot-filled in $100 \mathrm{ml}$ sterilized glass jars and capped with metallic lids, cooled and refrigerated at $4^{\circ} \mathrm{C}$. Jams were analyzed for physicochemical and sensory quality at weekly intervals for four weeks.

\section{Processing Trials}

In the processing trials, the treatment variations were: (a) $0.5 \%$ LM pectin , $0.5 \%$ calcium water and $1.6 \%$ sucralose, (b) $1.0 \%$ LM pectin, $1.0 \%$ calcium water and $2.4 \%$ sucralose, (c) $1.5 \%$ pectin, $1.5 \%$ calcium water and $4.0 \%$ sucralose and (d) $1.5 \%$ LM pectin, $1.5 \%$ calcium water and $6.3 \%$ sucralose. The standard formulation was comprised of $55 \%$ sorrel puree $(\mathrm{w} / \mathrm{w})$ with $0.1 \%$ xanthan gum, $0.5 \%$ sodium benzoate and $1.6 \%$ sodium hydroxide. The sorrel jam treatments were evaluated on flavor, sweetness, color, texture/mouthfeel, odor and overall acceptability by a focus groups comprising of 10 sensory panelists, who were between the ages of 18-22 years from the University of the West Indies. Each panelist had consumed sorrel products before such as drinks and wines. Based on the consensus that the initial jams were too soft, the subsequent jam treatments were modified to include $1.5 \%, 2.0 \%, 2.5 \% \mathrm{LM}$ pectin $\mathrm{w} / \mathrm{w}$.

Table 1. Formulations of Reduced-Calorie Sorrel Jam Treatments with Varying Levels of Low-Methoxyl Pectin

\begin{tabular}{|c|c|c|c|}
\hline Ingredient/ \% & $\mathbf{1 . 5 \%}$ Pectin & 2.0\% Pectin & 2.5\% Pectin \\
\hline \hline Sorrel puree & 55.0 & 55.0 & 55.0 \\
\hline Water & 32.3 & 2.0 & 2.3 \\
\hline Calcium water & 1.5 & 2.0 & 2.5 \\
\hline Pectin & 1.5 & 8.0 & 8.0 \\
\hline Splenda & 8.0 & 0.1 & 0.1 \\
\hline Xanthan gum & 0.1 & 0.05 & 0.05 \\
\hline Sodium Benzoate & 0.05 & & 2.5 \\
\hline
\end{tabular}


Frozen sorrel

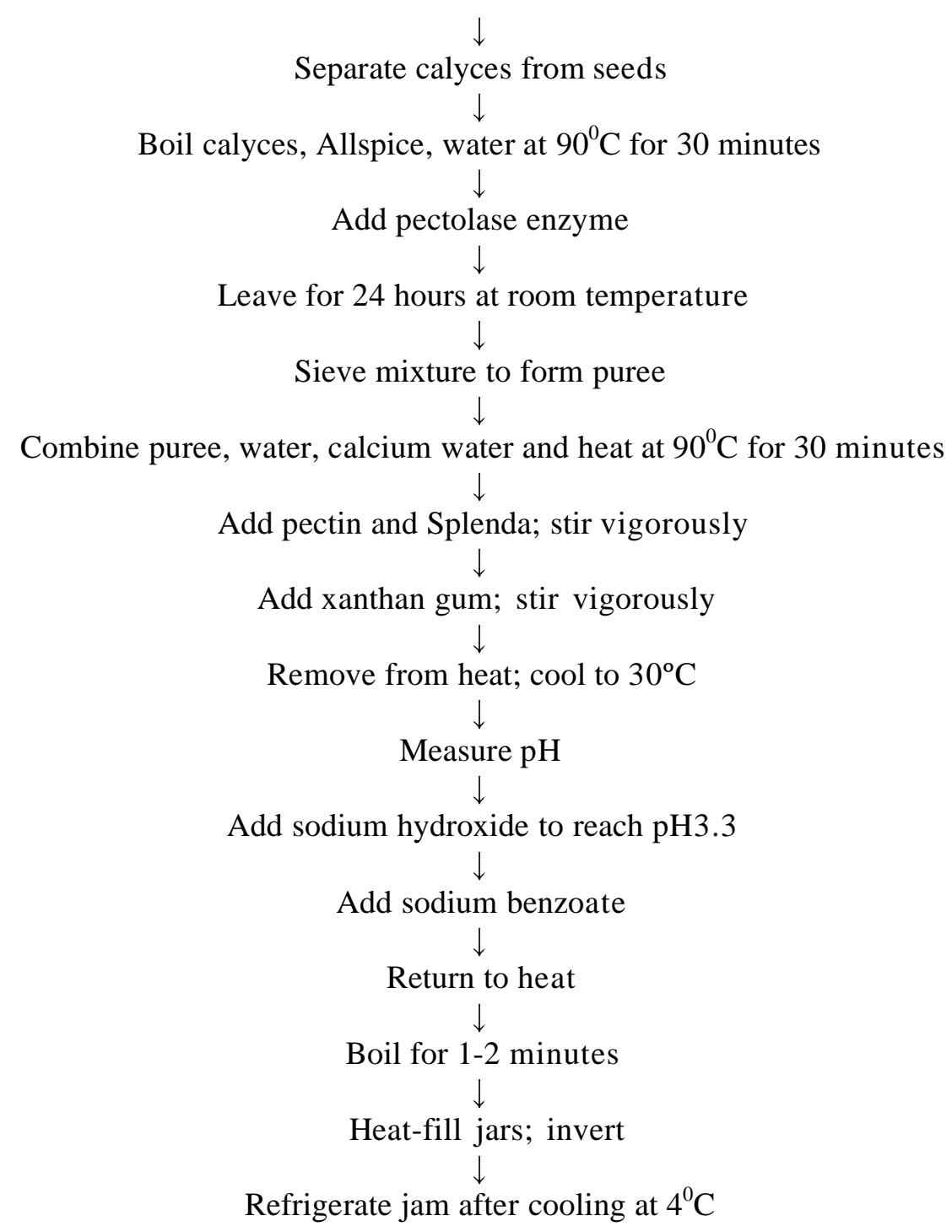

Fig. (1). Processing of Reduced-Calorie Sorrel Jam.

\section{Hedonic Testing}

The three reduced-calorie sorrel jams $(1.5 \%, 2.0 \%, 2.5 \%$ LM pectin) treatments were subjected to hedonic testing. The consumer acceptance test is a small panel test, usually involving only 50-100 panelists [46]. The consumer panel comprised of 50 volunteer panelists who were staff and students at the University of the West Indies. The demographic of consumers was $52 \%$ males and $48 \%$ females. The majority $(84 \%)$ of panelists was between $17-24$ yrs, $14 \%$ were $25-$ $32 \mathrm{yrs}$, and $20 \%$ were $33-40$ yrs. Ethnic distribution was as follows: $62 \%$ African, 12\% Indian, 2\% Caucasian, 20\% mixed and $4 \%$ as other. Persons were chosen randomly according to their previous use of sorrel products and according to their willingness to participate in the exercise. All participants were untrained and were reported to be in good health (self-report). Prior to the hedonic testing, the jams were removed from the refrigerator for about an hour. Consumer evaluation took place at Sensory Evaluation laboratory, Faculty of Science and Agriculture, University of the
West Indies, St. Augustine. Panelists were instructed that there was to be no communication between them so as not to influence each other's opinion. Before the start of each test, each panelist was provided with distilled water which they were to use to clean their palate before tasting each sample. Each panelist was provided with about 5 grams of each sample in a small clear plastic container with a $5 \mathrm{~cm}$ diameter and a $1 \mathrm{~cm}$ depth. The sample containers were placed upon a large white plate which was labeled in three areas with the sample number. Each sample was placed upon its respective number and the entire plate was then placed before the consumer. Each panelist was provided with a questionnaire and was asked to evaluate each sample based on flavor, sweetness, acidity, color, texture, odor and overall acceptability using a nine-point hedonic scale as follows: 1 - dislike extremely, 2 - dislike very much, 3 - dislike moderately, 4 dislike slightly, 5 - neither like nor dislike, 6 - like slightly, 7 - like moderately, 8 - like very much, 9 - like extremely [47]. Questions related to the use of sorrel products, low calorie products, jams of any type, awareness of health benefits of 
sorrel products, purchase intent of reduced -calorie jams and recommendations of reduced calorie sorrel jams to friends and family. A section of the questionnaire was also allocated for comments.

\section{Physicochemical Analyses}

The physicochemical analyses were conducted in triplicate on three sorrel treatments of $1.5 \%, 2.0 \%$ and $2.5 \%$ pectin directly at weekly intervals following manufacture. The total soluble solids (TSS) as ${ }^{\circ}$ Brix was measured on the sorrel puree and jam using refractometer (Leica Model Atago E Type Series; Leica Inc., Buffalo, NY, USA; 0-30 Brix).

The moisture content of the sorrel jam was determined by oven-drying (Quinay Lab Inc, Model \#40, GC-1 Chicago, Illinois, U.S.A) a $10 \mathrm{~g}$ sample of each sorrel jam treatment (wet sample weight) at $80^{\circ} \mathrm{C}$ for 48 hours.

The water activity of the samples was measured by first placing $10 \mathrm{~g}$ of the reduced calorie sorrel jam treatment into a small plastic container ( $3 \mathrm{~cm}$ diameter) and then by inserting the container into the measuring chamber of the Retronic Water Activity Meter (Aqua Lab CX-2, Retronic Instruments (UK) Ltd. Unit 1a Crompton Fields, West Sussex) for 15 minutes. Water activity values were directly recorded from the digital display at ambient temperature by taking three consecutive readings along with the temperature at which the reading was taken.

The color of the jam treatments was determined using the Tristimulus Minolta Chromameter (Model CR-200, Minolta Corp., Ramsey, N.J.) which uses the Judd-Hunter Lab solid color system. The apparatus was first calibrated using a white standard Minolta Calibration Plate Cr-A43. Within the solid color system, the following measurements were taken: $\mathrm{L}=$ lightness or darkness $(100=$ white, $0=$ black $),+\mathrm{a}=$ redness, $-\mathrm{a}=$ greenness. $+\mathrm{b}=$ yellowness, $-\mathrm{b}=$ blueness. Hue angle $\left(\mathrm{H}^{\circ}\right)$ were calculated from ' $\mathrm{a}$ ' and 'b' [48, 49]. $\mathrm{C}_{\mathrm{ab}}$ is a correlate visual for saturation and $\mathrm{H}_{\mathrm{ab}}$ a quantity that specifies hue numerically. The $\mathrm{H}^{\circ}$ of $0,45,90,180$ and 270 represented bluish red, orange, yellow, green and blue, respectively.

The texture of each jam treatment was measured with a Koehler Digital Penetrometer (Koehler Instrument Company Inc., Model K19550) using a 47.5g plunger with cone weight of $2.48 \mathrm{~g}$ (Model K20900). The cone was allowed to touch the surface of the sample which was compressed into a $40 \mathrm{ml}$ beaker to remove air pockets. The cone was then allowed to penetrate the sample for a set time of two seconds. Following this, the penetration depth was read from the apparatus which automatically records the depth. The depth was recorded as $\mathrm{mm} / 2$ seconds. The $\mathrm{pH}$ of the puree and the treatments was determined electronically using the Orion $\mathrm{pH}$ meter (Orion SP301, Thermo Orion, and U.S.A). The total titratable acidity (TTA) was expressed as \% citric acid after titration of $10 \mathrm{~g}$ of sorrel jam sample was titrated $\mathrm{w}$ with 0.1 $\mathrm{N} \mathrm{NaOH}$, with phenolphthalein end point of $\mathrm{pH} 8.33$ according to\# 962.12 [50].

\section{Microbiological Analyses}

Microbiological evaluation was conducted directly after processing of the sorrel reduced-calorie jam for each subsequent week during the jams' four week storage [51]. The evaluation was done to determine the presence of total col- ony forming units (CFUs) yeasts and molds and lactobacillus bacteria. The pour plate and spread plate techniques were used in this evaluation. Plate Count Agar (PCA; Difco, Detroit, MI, USA), Potato Dextrose Agar (PDA, Difco) and Tomato Juice Agar (TJA, Difco) were the media used for enumeration of total aerobes, yeasts and moulds and lactic bacteria. PCA and TJA media plates were incubated at $35^{\circ} \mathrm{C}$ for $48 \mathrm{~h}$ and PDA media plates at $25^{\circ} \mathrm{C}$ for $48 \mathrm{~h}$. Plates with 30-300 colonies were expressed as $\log _{10} \mathrm{CFUg}^{-1}$.

\section{Statistical Analyses}

All statistical analyses were performed using Minitab Statistical Software (Version 15, 2008, Minitab Statistical Software, Minitab Inc., Enterprise Drive State College, PA, USA) for Microsoft Windows. The results were analyzed by ANOVA and the significant means separated by LSD $(\mathrm{P}<0.05)$.

\section{RESULTS AND DISCUSSION}

\section{Focus Group Evaluation}

All sorrel jam treatments in the preliminary trials $(0.5 \%$ pectin with $1.6 \%$ sucralose; $1.0 \% \mathrm{LM}$ pectin and $2.4 \%$ sucralose, $1.5 \%$ LM pectin and $4.0 \%$ sucralose and $1.5 \% \mathrm{LM}$ pectin and $6.3 \%$ sucralose) had desirable colour. The reduced calorie sorrel jam with $1.5 \%$ LM pectin and $6.3 \%$ sucralose was most acceptable in sweetness. The texture of all the jam treatments was not acceptable due to low gel strength. Thus, the levels $(1.5 \%, 2.0 \%$ and $2.5 \% \mathrm{w} / \mathrm{w})$ of LM pectin were increased in order to improve gel strength. In addition, a higher level of sucralose $(8.0 \% \mathrm{w} / \mathrm{w})$ was used in order to increase the sweetness of the jams.

\section{Sensory Score Attributes}

Table 2 shows the effect of LM pectin (\%) on sensory attributes of reduced-calorie sorrel jam based on hedonic scores. There were no $(\mathrm{P}>0.05)$ differences in sensory color, odor, flavor, sweetness, acidity and overall acceptability between reduced-calorie sorrel jam treatments. However, the texture of the three jams treatments were significantly different $(p<0.05)$. The mean texture scores of reduced-calorie sorrel jams were $1.5 \%$ pectin - $6.67 \pm 0.20: 2.0 \%$ pectin $6.36 \pm 0.24$ and $2.5 \%-5.62 \pm 0.24(\mathrm{LSD}=0.637)$. According to McWilliams (1997), [52] the role of hydromethoxyl pectin is to form a network or create a thickening effect for jam to set. Hence, the more pectin used, the thicker the jam. Sorrel jam treatments of $1.5 \% \mathrm{LM}$ pectin and $2.5 \% \mathrm{LM}$ pectin were significantly $(\mathrm{P}<0.05)$ different. Hedonic scores varied from neither liked nor disliked to like slightly for the texture of the reduced-calorie sorrel jams. The texture of the jam may be further improved through the use of another gelling agent alone or in conjunction with LM pectin. Hercules Incorporated (1998) [53], indicated that in products with very low soluble solids such as sugar-free jams for diabetics, LM pectin has insufficient water binding properties and carrageenan is better suited for use. The inclusion of carrageenan is used to improve the mouth-feel (texture) of jam by thickening the product during the gelling process. In some instances, combinations of low-methoxyl pectin and carrageenan may offer some advantages.

There was no significant difference $(\mathrm{P}<0.05)$ in sweetness between the reduced-calorie sorrel jams. Sweetness was 
Table 2. Effect of Different Levels of Pectin on Hedonic Sensory Scores of Reduced-Calorie Sorrel Jam

\begin{tabular}{|c|c|c|c|c|}
\hline Parameter & $\mathbf{1 . 5 \%}$ Pectin & $\mathbf{2 . 0 \%}$ Pectin & $\mathbf{2 . 5 \%}$ Pectin & LSD \\
\hline \hline Colour & $7.8 \pm 0.2$ & $7.3 \pm 0.2$ & $7.0 \pm 0.2$ & - \\
\hline Odour & $6.6 \pm 0.2$ & $6.6 \pm 0.2$ & $6.3 \pm 0.2$ & N.S \\
\hline Texture & $6.7 \pm 0.2$ & $6.4 \pm 0.2$ & $5.6 \pm 0.2$ & 0.6 \\
\hline Flavour & $6.9 \pm 0.2$ & $6.3 \pm 0.2$ & $6.0 \pm 0.3$ & - \\
\hline Sweetness & $6.3 \pm 0.2$ & $6.2 \pm 0.3$ & $6.0 \pm 0.2$ & N.S \\
\hline Acidity & $6.1 \pm 0.2$ & $6.2 \pm 0.3$ & $5.8 \pm 0.3$ & N.S \\
\hline Overall Acceptability & $6.8 \pm 0.2$ & $6.7 \pm 0.2$ & $6.4 \pm 0.2$ & N.S \\
\hline
\end{tabular}

rated with hedonic scores of $6.02 \pm 0.23$ to $6.32 \pm 0.22$, denoting that reduced calorie jams were slightly liked by consumer panellists who were non-diabetic. Splenda in the form of sucralose has been noted to taste like sugar, has a clean, quickly perceptible sweet taste and does not have an unpleasant aftertaste attributed to other low-calorie sweeteners [54]. It also consists partially of the bulking agent maltodextrin which provides texture to the jam and adds solids [55]. In a study on internal preference mapping and cluster analysis of strawberry jam showed two consumer clusters, a higher concentration of consumers towards traditional samples and a second one showed a lower concentration of consumers in the direction of one of the low-calorie samples [56]. The least accepted samples were the ones with the lowest sweetness intensity, indicating that jam consumers prefer sweeter products.

\section{Physicochemical Properties}

Table 3 shows the physiochemical properties of reducedcalorie sorrel jam treatments. The moisture content of the jams increased $(\mathrm{P}<0.05)$ significantly with the increase of low-methoxyl pectin $(1.5 \%-16.3 \% \pm 0.01 ; 2.0 \%-16.4$ $\pm 0.00 ; 2.5 \%-17.4 \pm 0.01)$ which reflects the ability of LM pectin to trap water within its matrices. There was a decline $(\mathrm{P}<0.05)$ in water activity of the reduced-calorie sorrel jams with higher levels of LM pectin (1.5\% LM pectin $0.815 \pm 0.001 ; 2.0 \%$ LM pectin - $0.801 \pm 0.001 ; 2.5 \%$ LM pectin $-0.786 \pm 0.001)$. Water activity $\left(\mathrm{A}_{\mathrm{w}}\right)$ determines the lower limit of available water for microbial growth [57]. In gen- eral, the minimum $\mathrm{A}_{\mathrm{w}}$ for most moulds is 0.8 , most yeasts 0.85 and osmophilic yeasts 0.6-0.7 [58].

The reduced-calorie sorrel jam with $2.0 \% \mathrm{LM}$ pectin was significantly $(\mathrm{P}<0.01)$ darker, most chromatic and least red when compared to $1.5 \%$ low methoxyl pectin and $2.5 \%$ lowmethoxyl pectin products (Table 3 ).

Texture became $(\mathrm{P}<0.05)$ firmer (lower penetrometer values) with higher levels of LM pectin. The TTA as \% citric acid significantly $(\mathrm{P}<0.001)$ decreased from $0.96 \pm 0.008$ for $1.5 \% \mathrm{LM}$ pectin to $0.82 \pm 0.001$ for $2.5 \% \mathrm{LM}$ pectin. The dominating acids were identified as citric and hibiscus acids in calyces of five sorrel strains originating from Egypt, Senegal, India, Thailand and Central America [59]. Citric acid predominates (12-17\%), but malic and tartaric acids are also present in red sorrel [60]. Pectin glycosidic linkages hydrolyze in strong acidic mediums [61]. Hence, an increase in pectin would result in the removal of more $\mathrm{H}^{+}$ions from the solution. LM pectin gelation occurs in the presence of $\mathrm{Ca}^{2+}$ ions, both with and without sugar [62]. The proposed mechanism is based on the described 'egg-box model' [63, 64].

The TSS of the sorrel puree was $6^{\circ}$ Brix and was constant at $16^{\circ}$ Brix for all reduced-calorie sorrel jams. Traditional jams carry up to $65^{\circ}$ Brix according to CODEX STAN 79-8 [2] However, all jams formulated in this study carried 16 Brix, hence why they were labeled as reduced-calorie jams. The study by Gajar and Badrie (2001) [65] showed that the increase in TSS from $4^{\circ}$ Brix in raw christophene to $12^{\circ}$ Brix

Table 3. Effect of Low-Methoxyl Pectin on the Physicochemical Quality of Reduced-Calorie Sorrel Jam Treatments

\begin{tabular}{|c|c|c|c|c|c|}
\hline Parameter & $\mathbf{1 . 5 \%}$ & $\mathbf{2 . 0 \%}$ & $\mathbf{2 . 5 \%}$ & LSD & 0.1 \\
\hline \hline Moisture Content (\%) & $16.3 \pm 0.0$ & $16.4 \pm 0.0$ & $17.4 \pm 0.0$ & 0.001 \\
\hline Water Activity (Aw) & $0.8 \pm 0.0$ & $0.8 \pm 0.0$ & $0.8 \pm 0.0$ & 0.0 \\
\hline L Value & $21.1 \pm 0.2$ & $20.2 \pm 0.3$ & $22.3 \pm 0.1$ & 0.000 \\
\hline Chroma & $4.7 \pm 0.1$ & $5.4 \pm 0.1$ & $4.3 \pm 0.1$ & 0.0 \\
\hline Hue & $14.2 \pm 0.4$ & $22.9 \pm 1.9$ & $16.4 \pm 0.5$ & 0.0 \\
\hline Texture (mm/2s) & $25.4 \pm 0.2$ & $10.6 \pm 0.3$ & $8.3 \pm 0.1$ & 0.036 \\
\hline TTA (\% citric acid) & $1.9 \pm 0.0$ & $0.9 \pm 0.0$ & $0.8 \pm 0.0$ & 0.000 \\
\hline
\end{tabular}


Table 4. Effect of Storage on the Physiochemical Properties of Reduced -Calorie Sorrel Jam Treatments During Storage

\begin{tabular}{|c|c|c|c|c|c|c|}
\hline Parameter & Wk 1 & Wk 2 & Wk 3 & Wk 4 & LSD & $\mathbf{p}$ \\
\hline Moisture Content, (g) & $8.3 \pm 0.0$ & $8.3 \pm 0.0$ & $8.4 \pm 0.0$ & $8.4 \pm 0.0$ & - & N.S \\
\hline Water Activity, (Aw) & $0.8 \pm 0.0$ & $0.8 \pm 0.0$ & $0.8 \pm 0.0$ & $0.8 \pm 0.0$ & - & N.S \\
\hline L Value & $22.8 \pm 0.91$ & $21.4 \pm 0.3$ & $20.5 \pm 0.7$ & $20.0 \pm 0.4$ & 1.5 & 0.01 \\
\hline Chroma & $4.7 \pm 0.1$ & $4.8 \pm 0.1$ & $4.8 \pm 0.1$ & $5.0 \pm 0.1$ & - & N.S \\
\hline Hue & $26.0 \pm 2.0$ & $16.1 \pm 0.4$ & $13.2 \pm 0.5$ & $16.0 \pm 0.4$ & 7.2 & 0.01 \\
\hline Texture, $(\mathrm{mm} / 2 \mathrm{~s})$ & $14.8 \pm 1.2$ & $15.8 \pm 1.3$ & $14.0 \pm 1.4$ & $14.4 \pm 1.4$ & - & N.S \\
\hline TTA (\% citric acid) & $0.9 \pm 0.0$ & $0.9 \pm 0.0$ & $0.9 \pm 0.0$ & $0.9 \pm 0.0$ & - & N.S \\
\hline
\end{tabular}

was caused by the concentration effect during processing and the addition of an artificial sweetener, pectin and carrageenan. Results also stated that the $\mathrm{pH}$ of the jams remained constant at 3.3. The $\mathrm{pH}$ of the solution containing the pectin must be between 3.2 and 3.6 to form a gel [66].

\section{Storage Effects}

There were no significant differences $(\mathrm{P}>0.05)$ in moisture content, water activity, chroma, texture or TTA during the four weeks of storage at $4^{\circ}$ (Table 4). Sorrel jams were $(\mathrm{P}<0.01)$ darker and less red on storage. These color changes were also observed on storage of sorrel leather for 4 weeks at $4^{\circ} \mathrm{C}[41]$.

The microbial results indicated that the sorrel jams had

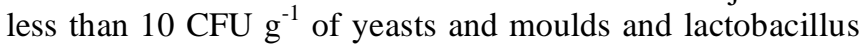
bacteria. The pasteurization process, low $\mathrm{pH} 3.3$, inclusion of $0.05 \%$ sodium benzoate and the storage temperature of $4{ }^{\circ} \mathrm{C}$ prevented microbiological growth in reduced-calorie sorrel jam during 4 weeks of storage. In an artificially sweetened jelly, the use of sodium benzoate or benzoic acid (0.05 $0.10 \%$ ) was used for microbial stability [67].

\section{Utilization}

A limitation of the survey is that none of the panellists was diabetics, although $52 \%$ had family members who were diabetic. The majority of the consumer panellist had consumed jams (76\%), sorrel products $(96 \%)$ and sorrel drinks $(92 \%)$. Only $38 \%$ had consumed low-calorie products and $32 \%$ had utilized sorrel as jam. Hence for the majority of the panellists, the reduced-calorie sorrel jam would have been a new product. Most (76\%) would purchase the reduced calorie sorrel jam and $82 \%$ would recommend the product to friends and families.

\section{CONCLUSION}

Of all the sensory attributes, texture was significantly affected by the addition of LM pectin in reduced-calorie sorrel jams. A reduced-calorie sorrel jam containing $1.5 \%$ lowmethoxyl pectin and $8 \%$ sucralose was $16^{\circ}$ Brix was slightly to moderately liked in texture with an overall acceptance. The product has a shelf-life of at least 28 days at $4^{\circ} \mathrm{C}$. This research shows that formulating a low-calorie jam using Splenda and low-methoxyl pectin can be achieved with acceptable sensory attributes that may be marketed for diabetic persons or the health conscious consumers. Several points in dietary advice were identified in diabetes management [68].

\section{ACKNOWLEDGEMENTS}

Gratitude is extended to Mr. E. Mohammed, Mrs. V. De Gannes and Mr. K. John of the Department of Food Production, Faculty of Science and Agriculture, University of the West Indies, St. Augustine for their technical assistance.

\section{REFERENCES}

[1] Sandrou D, Arvanitoyannis I. Low-fat/calorie foods: current state and perspectives. Crit Rev Food Sci Nutr 2000; 40 (5): 427-447.

[2] CODEX STAN 79. Standard for jams (fruit preserves) and jellies: processed and quick frozen fruits and vegetables. Geneva: FAO/ WHO Food Standards 1981

[3] Franz J. Nutritional care in diabetes mellitus and reactive hypoglycemia. In: Escott MK, Stump S, Eds. Krause's food, nutrition and diet therapy. Philadelphia, Pennsylvania: W.B. Aunders Co: 1996; p. 681 .

[4] Goldsmith L, Merkel C. Sucralose: In: Nabors, LO, Ed. Alternative sweeteners. $3^{\text {rd }}$ ed. New York: Marcel Dekker Inc. 2001; pp.185207.

[5] Chaplin M. Water structure and science: pectin: wales creative commons. 2009. Avalibale: http://www.martin.chaplin.btinternet.co.uk/index.html, [Accessed 17th April, 2009].

[6] Sila DN, Buggenhout SV, Duvetter T, et al. Pectins in processed fruits and vegetables: part 11- Structure and function relationships. Comp Rev Food Sci Food Saf 2008; (8): 86-104.

[7] Meyer L. Food chemistry. New York, USA: Reinhold Publishing Corporation 1960.

[8] Prosky L. Advanced dietary fibre technology. USA: Oxford: Blackwell Science 2001.

[9] Wild S, Roglic G, Green A, Sicree R, King H. Global prevalence of diabetes: estimates for the year 2000 and projections for 2030. Diabetes Care 2004; 27 : 1047-53.

[10] Xuereb GC, Ragoobirsingh D. The prevalence of diabetes in the Caribbean. CAJANUS 2006; 39 (3): 119-24.

[11] CAJANUS. Non-communicable diseases- Diabetes and obesity. CAJANUS 2006a; 39 (4): 183-4.

[12] CFNI. Obesity prevention and control- The Caribbean experience. Caribbean Food and Nutrition Institute. Jamaica: Mona 2001.

[13] CAJANUS. Non-communicable diseases- Obesity. CAJANUS 2006; 39 (4): 204-14.

[14] Hennis A, Wu Suh-Yuh, Nemesure B, Li Xiaowei LCM. Diabetes in a Caribbean Population: epidemiological profile and implications. Int J Epidemiol 2002; 31: 234-9.

[15] Purseglove J. Tropical Crops: Dicotyledons 2. London: Longmans Green and Co. Ltd. 1968; pp. 371-73.

[16] Du CT, Francis, F.J. Anthocyanins of roselle (Hibiscus sabdariffa L.). J Food Sci 1973; 38: 810-2. 
[17] Matsa A, Isa PM, Abd Aziz, A.R. Analisis kimia da pemprosesan roselle (Hibiscus sabdariffa L.). MARDI Res Bull 1985; 13: 68-74.

[18] Tee P-L, Yusof S, Mohamed S, Umar NA, Mohammed, NM. Effect of roselle (Hibiscus sabdariffa L.) on serum lipids of Sprague Dawley rats. Nutr Food Sci 2002; 32: 190-6.

[19] Tsai P, Mc Intosh J, Pearce P, Camden B, Jordan BR. Anthocyanin and antioxidant capacity in roselle (Hibiscus sabdariffa L.) extract. Food Res Int 2004; 35: 351-6.

[20] Pouget MP, Vennat B, Lejeune B, Pourrat A. Identification of anthocyanins of (Hibiscus sabdariffa L.). Lebensmittel Wissenchaft Technol 1990; 23: 101-2.

[21] Markakis P. Stability of anthocyanins in foods. Anthocyanins as Food Colours. London: Academic Press 1982; pp.163-78.

[22] Kalt W, McDonald JE, Donner H. (2000). Anthocyanins, phenolics, and antioxidant capacity of processed lowbush blueberry products. J Food Sci 2000; 65: 390-3.

[23] Skrede G, Wrolstad RE, Durst R W. Changes in anthocyanins and polyphenolics during juice processing of highbush blueberries (Vaccinium corymbosum L.). J Food Sci 2000; 65: 357-64.

[24] Morton JF. Roselle. Fruits of the warm climate. In: Dowling CF, Ed. Greensborough, NC USA: Media Inc. 1987; pp. 281-286.

[25] Wrolstad RE. Interaction of natural colours with other ingredients: anthocyanin pigments-bioactivity and colouring properties. J Food Sci 2004; 69: C419-C21.

[26] Murakoshi M, Nishino H, Satomi Y. et al. Potent preventive action of b-carotene against carcinogenesis: spontaneous living carcinogenesis and promoting state of lung and skin carcinogenesis in mice are suppressed more effectively by a-carotene than by $\beta$ carotene. Cancer Res 1992; 52: 6583-7.

[27] Hertog MGL, Feskens EJM, Hollman PCH, Katan MB, Kromhout D. Dietary antioxidant flavonoids and risk of coronary heart disease: The Zupten Eldery Study. Lancet 1993; 342: 1007-11.

[28] Hertog MG, Kromhout D, Aravanis C, et al. Flavonoid intake and long-term risk of coronary heart disease and cancer in the seven countries study. Arch-Intern-Med 1995; 155: 381-6.

[29] Bridle P, Timberlake CF. Anthocyanins as natural food colourselected aspects. Food Chem 1997; 58: 103-9.

[30] Tseng TH, Hsu JD, Lo MH, et al. Inhibitory effect of Hibiscus protocatechuic acid on tumor promotion in mouse skin. Cancer Lett 1998; 126: 199-207.

[31] Delgado-Vargas F, Jiménez AR, Paredes- López, O. Natural pigments: carotenoids, anthocyanins, and betalains - characteristics, biosynthesis, processing and stability. CRC Crit Rev Food Sci Nutr 2000; 40: 173-289.

[32] Gibson GR, Williams CM. Introduction. In: Gibson GR, Williams CM, Eds. Cambridge UK: Functional FoodsWoodhead Publishing Ltd. 2000; pp. 1-5.

[33] Murkovic MH, Toplak U, Adam U, Pfannhauser W. Analysis of anthocyanins in plasma for determination of their bioavailability. $\mathrm{J}$ Food Compos Anal 2000; 13: 291-6.

[34] Prior RL, Cao G. Antioxidant phytochemicals in fruits and vegetables: diet and health implications. HortScience 2000; 35: 588-92.

[35] Porter MLM, Krueger CG, Wiebe DA, Cunningham DG, Red J. Cranberry procyanidins and inhibit in vitro $\mathrm{Cu}^{2+}$-induced oxidation. J Sci Food Agric 2001; 81: 1306-13.

[36] Bors W, Michel CA. Chemistry of the antioxidant: effect of polyphenols. Ann NY Acad Sci 2002; 957: 57-9.

[37] Mounigan P, Badrie N. Physicochemical and sensory quality of wines from red sorrel/roselle (Hibiscus sabdariffa L.) calyces: effects of pre-treatments of pectolase and temperature/time. Int J Food Sci Technol 2007a; 42(4): 469-75.

[38] Mounigan P, Badrie N. Roselle/sorrel (Hibiscus sabdariffa L.) wines with varying calyx puree and total soluble solids : sensory acceptance, quantitative descriptive and Physicochemical analysis. J Food Serv 2007b; 17: 102-10.

[39] D'Heureux-Calix F, Badrie N. Consumer acceptance and physicochemical quality of processed red sorrel/roselle (Hibiscus sabdariffa L.) sauces from enzymatic extracted calyces. Food Serv Technol 2004; 4: 141-8.
[40] Henry H, Badrie N. Utilisation of sorrel/roselle (Hibiscus sabdariffa L.) nectar in stirred yoghurts: physicochemical and sensory quality. J Food Technol 2007; 5 (1): 55-61.

[41] Jueanville M, Badrie N. Processed sorrel/roselle (Hibiscus sabdariffa L.) Leather from pectolase -treated calyces. Effects of xanthan gum on physicochemical quality and sensory acceptance. J Food Technol 2007; 5 (2): 164-8.

[42] Chen CC, Hsu JD, Wang SF, et al. Hibiscus sabdariffa extract inhibits development of artherosclerosis in cholesterol -fed rabbits. J Agric Food Chem 2003; 51: 5472-7.

[43] Amusa NA, Ashaye OA, Aiyegbayo AA, Oladapo MO, Oni MO, Afolabi OO. Microbiological and nutritional quality of hawked sorrel drinks (soborodo) (theNigerian locally brewed soft drinks) widely consumed and notable drinks in Nigeria. J Food Agric Environ 2005; 3 (3\&4): 47-50.

[44] Mazza G, Miniati E. Anthocyanin in Fruit. Vegetables and Grain. Boca Raton FL: CRC Press 1993.

[45] Rolin C. Pectin. In: Whistler RL, Bemiller JN, Eds. Industrial Gums: Polysaccharides and their Derivatives. New York, NY USA: Academic Press 1993; pp. 257-93.

[46] Resurrection A. Consumer sensory testing for product development. Maryland: Aspen Publishers 1998.

[47] Lawless T, Heymann H. Sensory evaluation of food. New York USA: Chapman and Hall 1998.

[48] Francis FJ. Colour analysis. In: Nielsen SS, Ed. Food Analysis. Gaithersburg, MD: Aspen Publishers 1998; pp. 601-611.

[49] Mac Dougall DB. Colour measurement of food principles and practice. In: MacDougall DM, Ed. Colour in food improving quality. Boca Raton, Fl: CRC Press 2000; pp. 33-63.

[50] AOAC. Official Methods of Analysis. AOAC International. Gaithersburg, MD: Association of Analytical Chemists 1995.

[51] APHA. Colony count methods In: Vanderzant C, Splittstoesser DF, Eds. Compendium of methods for the microbiological examination of foods. Washington, DC: American Public Health Association 1992; pp. 75-94, 225-236, 239-245.

[52] McWilliams M. Food-experimental perspectives. Columbus, Ohio: Prentice Hall 1977; pp. 118, 588.

[53] Hercules Incorporated. Hercules Division Pectin Fruit-Based Products Application Guide. Copenhagen, Denmark: A Division of Hercules Incorporated. 1998; DK-4623.

[54] Whitney E, Rolfes S. Alternatives to sugar. In: Understanding Nutrition. St. Paul, M.N: West Publishing Co. 1996; pp. 146-151.

[55] Deis R. Low-calorie and bulkening agents. Food Technol 1993; 47 (2): 94-6.

[56] Alves LR, Battochio JR, Cardoso JMP, et al. Time-intensity profile and internal preference mapping of strawberry jam. J Sens Stud 2008; 23: 125-35.

[57] Decagon Devices Inc. [homepage on the internet]. What is Water Activity? Pullman, WA, U.S.A 2007 (cited 2007 March $8^{\text {th }}$ ). Available from http://www.decagon.com/aqualab/aw_info.html. 2007. [Accessed: March $8^{\text {th }}$, 2007].

[58] Ray B. Fundamental food microbiology. Boca Raton, Florida: CRC Press 1996.

[59] Khafaga E-SR, Koch H. Stage of maturity and quality of roselle (Hibiscus sabdariffa L. var. sabdariffa). 1 Organic acids. Angewandte Botanik 1980; 54: 287-93.

[60] Kerharo J. Senegal bissap (Hibiscus sabdariffa) or Guinea sorrel or red sorrel. Plant Med Phytother 1971; 5: 277-81.

[61] Belitz H, Grosh W. Pectin. Food Chemistry. New York USA: Springer-Verlag 1999; pp. 295-296.

[62] Löfgren C, Walkenström P, Hermansson M. Microsturcture and rheological behaviour of pure and mixed pectin gel. Biomacromolecules 2002; 3 (6): 1144-453.

[63] Grant GT, Morris ER, Rees DA, Smith PJC, Thom, D. Biological interactions between polysaccharides and divalent cations: the eggbox model. FEBS Lett 1973; 32 (1): 195.

[64] Morris ER, Powell DA, Gidley MJ, Rees DA. Conformations and interactions of pectins 1. Polymorphism between gel and solid states of calcium polygalacturonate. J Mol Biol 1982; 115: 507-16. 
[65] Gajar M, Badrie N. Processing and quality evaluation of lowcalorie christophene jam. J Food Sci 2001; 67 (1): 344-5.

[66] Frey JA. The effects of sugar, pectin on gel strength in a naturally low and high pectin fruit varieties. Lafayette, Purdue University: Dietetics, Nutrition Fitness and Health Double Major 2005; p.24; http://www.cfs.purdue.edu/fn/fn453/Project_Archive/Fall_2005/Va riables_affecting_get_strength_in_pectin_jellies.pdf
[67] Hodgson A, Kerr L. Tropical fruit products. In: R.H. Walter, Ed. The chemistry and technology of pectin. San Diego, CA: Academic Press, Inc. 1991; pp. 67-86.

[68] Scott P. Diabetes nutrition education and human rights: lessons from a research study among Caribbean people in the UK. CAJANUS 2006; 39 (3): 145-53.

(C) Broomes and Badrie; Licensee Bentham Open.

This is an open access article licensed under the terms of the Creative Commons Attribution Non-Commercial License (http://creativecommons.org/licenses/by-nc/3.0/) which permits unrestricted, non-commercial use, distribution and reproduction in any medium, provided the work is properly cited. 